\title{
Implementation of Human Rights Values in Historical Learning in Educations
}

\section{Ahmad Ruslan ${ }^{1 *}$, Abdul Syukur², Kurniawati ${ }^{3}$}

${ }^{123}$ Postgraduate Historical Education Study Program, State University of Jakarta, East Jakarta, Indonesia

A R T I C L E I N F O

Article history:

Received 10 August z2020

Received in revised

Form 13 September

2020

Accepted 3 October

2020

Available online 01

November 2020

Keywords:

Human Rights, History

Study, Equality,

Discrimination

\section{A B S T R A C T}

Human rights abuses are the center of every country in the world, as they are the result of their dominance over the weak, or other things like ignorance, lack of law enforcement, etc. And so it is in the world of education, which ought to be a center of understanding and awareness of human rights, through history study. But rather often, human rights abuses come from academic environments such as schools and colleges. The study aims to analyze the implementation of human rights values in history study. The study uses a qualitative method with a library research approach, whereas the datacollecting technique is a document or documentary study instrument. These findings suggest that the study of history has affected the behavior of students that reflect the virtues of human consciousness. Human rights values such as equality and the ban of discrimination (nondiscrimination) are reflected in students after the historical learning process is done, it can be seen both inside and outside the equation. Thus history study alone has significant effects on students, such as mutual respect of opinion, upholding the values of tolerance, cooperation and so forth. The conclusion of the article is that the effectiveness of learning needs to be optimized so that the human rights reflected in every historical event are capable of being thoroughly analyzed and understood by learners, which are then a provision for students to live national and national.

\section{Introduction}

In Indonesia, human rights are positioned in a respectful place, after acknowledging their position and efforts to prevent violations, human rights are always encouraged to be implemented as the best in customary law and other laws since the kingdom, colonial and post-colonial era. However, in practice, sometimes there are still many problems (Asplund, 2009; Emmert \& Eur, 2011; Suhadi, 2007). This means that there are still a large number of human rights violators. Even though, in total, theoretical superstition, Indonesian society is not alien to human rights terms. However, human rights are a fundamental thing inherent in human beings themselves, which everyone has the right to receive and has the obligation to respect them, as a person (individual) or as a social morality (group) (Asplund, 2009; Triputra, 2017).

Basically humans are special creatures, both philosophically and in their present-oriented development, holding on to the past and having future projections. "... exposure to the philosophy of human action, as the main activity in vitality active. Man, as an individual, is body and soul; soul and mind. Identity is understood not only as the present, but also as the past and projections of the future. Humans develop continuously in time historicity, so that each individual is unique from the other" (Indah, 2015; Ruslan \& Syukur, 2020).

The problems that occur are more complicated when the expected government is present as an intermediary for even solutions to problems, sometimes missteps in overcoming various conflicts that occur. For example, handling through repressive actions that are violent and tend to be militaristic. For example, the Peristiwa Tragedy Semanggi in 1998, the Student demonstrations in 1998, the Ambon conflict in 1999, the conflict in Poso in 2000, the handling of the conflict in West Papua in 2019, then those which were still very strong in student demonstrations in 2019 and many other Christians (Ruslan \& Syukur, 2020; Widodo, 2011).

Other events that occurred were not only during the governmental satellite, the phenomenon of human rights violations also occurred in educational institutions, such as schools and colleges. Few 
educational institutions pay attention to human-friendly contexts. This means that there are not many educational institutions that are sensitive to human use, both at school and in college. For example, in terms of facilities, toilets that are not friendly to people with disabilities, steep stairs that are dangerous to pregnant women, rules of educational institutions that do not fulfill the rights of educated students, campus nuances that restrain student aspirations and others.

Discussing human rights violations, human rights violations itself is every act of a person or group of people including state officials whether on purpose or negligence, limiting, and / or suppressing the enthusiasm of a person or group of people guaranteed by law (Asplund, 2009; Shekarey et al., 2010). Ideally, an educational institution in which a scientific culture and moral lessons will be the place for all the right solutions to human basic consciousness. However, reality is different in the field, on the contrary, there are many times when human rights violations are committed by educators and students. For example, the violence that occurs with students being educated by educators, excessive (inhuman) punishment for students, there is also stabbing of students to lecturers, culture or culture of sexual harassment students, discriminatory behavior and others. So that it creates anomalies, then what is produced from education if these things still happen and cannot be avoided.

The learning process in classrooms, whether at school or high-level teachers, ideally fosters awareness of the importance of human resources. Especially when we see that the values of humanity are included in the material and primarily for students to be educated both in schools and in universities. For example, lectures or courses on Religious Education, Citizenship, History, and other social disciplines. For example, in religious education, it cannot be denied that the teachings of goodness have been confirmed through discussions, kindness of worship to God or advice to do good for humanity and the environment. The same is the case with Citizenship Education, which not only talks about national matters, it also talks about national issues, harmony, tolerance, tolerance, solidarity, being a good citizen and so on.

Apart from religious education and Citizenship Education, historical education is not of less importance in introducing human rights. Historical learning should be directed to learning by doing and learning how to learn, which in turn means that a wise history teacher must make history a teacher of life (Košir \& Lakshminarayanan, 2020; Widodo, 2011; Wong et al., 2020). That is, historical events that occur, are not sufficient if they are made into a periodic sequence of events, without any reflection in them. There is a need for meaning in every powerful historical event to be conveyed in the classroom, so that the lessons learned in every historical event that are conveyed can be felt and implemented by participants as lessons learned and life improvement later on.

One way that can be used is by reflective learning. Reflective learning is a model that can be used to teach historical empathy. The role of a teacher, educator, teacher and tutor is needed to increase the place of history, especially in helping students to make effective connections with the past (Isenström \& Quennerstedt, 2020; Utami, 2019). By intertwining the values of empathy, researchers see the potential that reflective learning can also be used as a trigger for human rights awareness values that can be circulated in every historical learning process. With the hope that humanitarian problems can be formulated through an educational culture that teaches knowledge of human values and awareness of Human Rights.

This study aims to analyze the implementation of human rights values in history learning in higher education. So far, there has been no specific research on the implementation of human rights values in history learning, especially in universities. Whereas in fact in every historical event, the practice of human rights violations often colors every chronolology of historical events which is a valuable provision for learning human life in the present and the future.

\section{Methods}

This study uses a qualitative method. Meanwhile, data collection techniques use interview instruments and document or documentation study (Sugiyono, 2012). Interviews were conducted with two lecturers and twenty students at two universities in Jakarta. In addition, researchers also sought reinforcement from competent figures in the fields of education, human rights and history learning. Then the researcher also examines other studies related to the focus of research on the implementation of human rights awareness values in history learning.

Meanwhile, for the data analysis technique, the researcher used the Miles and Huberman model (Sugiyono, 2012) with the following stages: (1) Data reduction is an activity of summarizing, selecting, and focusing on important things to then look for themes and patterns, and further eliminate unnecessary things; (2) Presentation of data is an activity when the data that has been previously reduced is organized and arranged in a relationship pattern, so that the researcher will find it easier to understand the data that has been obtained during the study; (3) Conclusion or verification, which is the final stage when the 
findings obtained answer the formulation of the problem or purpose stated from the start, so that an object of research that was previously unclear or dark becomes clear after a research is carried out.

\section{Result and Discussion}

Human rights are not new, their development history covers a number of centuries, in the early 13th century on the British continent, which is famous for its Charter Magna Charta (1215), and the Petition of Rights (1689). Human rights is a universal value, so that the nation and state of Indonesia, as citizens of the world community cannot be apathetic. The implementation of human rights values in the constitutional state of Indonesia must be formulated in clear and firm laws and regulations on how to carry out and defend them. Reviewed objectively, human rights are an inherent authority in humans as humans, which the government must acknowledge and respect (Bajaj, 2012; Triputra, 2017). Referring to this, ideally all elements realize that human rights are not something that can be seen by the eye. Lots of people in society are deprived of their rights, on the basis that local, national, and even international human rights values have been an existing guideline for a long time.

Human rights are rights that are owned only by human beings, not because they are given by society, or based on positive laws, but solely based on their dignity as humans (Bedau, 2016; Emmert \& Eur, 2011). This means that even though everyone is born with various differences, such as skin color, sex, language, culture and different nationalities, they still have these rights. This is what is meant by the universal nature of Human Rights.

Several principles have inspired international human rights, among others: The principle of equality is an idea that puts everyone born free and has equal rights in human rights, in situations that should be treated equally and in different situations treated differently (Kim, 2019; Manuchehr, 2010). All people are equal humans. Specifically, Article 1 of the UDHR states that: "Every human being is born free and equal in dignity and dignity". That is, if we acknowledge that it hurts to humankind and we live together, we should take care of these equality values. Not because different wealth, position, intelligence as if human dignity and dignity are different, but they are not. Humans are all the same and equal.

This is what is often forgotten, even tends to be violated by most people. Assuming that himself, his group, and the organization are superior, and then all things that are different are made into actions that violate the principle of equality. In other words, the principle of equality is something that is often considered unimportant, whereas in essence human beings are the same and are the principles that are protected in Human Rights.

Furthermore, the prohibition of discrimination (non discrimination). If everyone is considered to be equal, then there should be no discriminatory treatment as well as affirmative action in order to achieve equality. Basically, discrimination is a difference in behavior from treatment that should be equal or equal (Kim, 2019; Manuchehr, 2010; McLeod, 2014). Non-discrimination is integrated and very close to equality. This principle ensures that no one can exclude other people because of external factors, such as harmony, color, skin, sex, language, religion, politics or other views, nationality, ownership of birth status or other (Rodrigues, 2020; Shekarey et al., 2010).

An example in the research entitled Gender Identity: The Human Right of Depathologization, found that the current situation for trans people in relation to legal health issues, depends on the country. Human rights are universal, not a question of cultural interpretation. They are the minimum that must be guaranteed by every human being only in fact as humans. Countries should protect rights by regulating trans-pathology with special attention dedicated to intersex people and their specific needs (CastroPeraza et al., 2019; Wong et al., 2020).

\section{Human Rights in Learning History}

Historical learning is a branch of science that examines the origins and development and culture of society in the past which contains wisdom values that can be used to train intelligence, shape the attitudes, character and personality of students (Jumardi, 2017; Permatasari, 2014). Learning history serves to make students aware of the process of change and development of society in the dimension of time and to build historical perspectives and awareness in discovering, understanding, and explaining national identity in the past, present, and future in the midst of changing world. History learning is also a way to shape social attitudes. The social attitudes include: mutual respect, respect for differences, tolerance and a willingness to live side by side in nuances of multiculturalism (Jumardi, 2017; Soraya et al., 2018).

The important role of historical learning is not only as a process of transferring ideas, but also as a process of maturing participants who are educated to understand national identity, identity and personality through understanding historical events. The objectives of historical learning are: (1) Develop 
an understanding of yourself; (2) Give an accurate picture of the concepts of time, space and society; (3) Make participants able to evaluate the value and results achieved by the generation (4) Teaches tolerance; (5) Extending the horizons of electricality; (6) teach moral principles; (7) Instill orientation towards the future; (8) Train participants to deal with controversial issues; (9) Helping to provide a means for social and individual problems; (10) Strengthening the sense of nationalism; (11) Develop international understanding; (12) Developing useful skills (Horohiung, 2017; Jumardi, 2017).

It has been a guidebook that has existed for a long time. Human rights are rights possessed by humans solely because they are human, not because they are given by society, or based on positive law, but solely based on their dignity as humans (Bedau, 2016). In this sense, even though everyone is born with various differences, such as skin color, gender, language, culture and nationality, they still have these rights. This is the universal nature of human rights (HAM). These rights cannot be revoked (inalienable). This means that no matter how bad the treatment has been experienced by someone or no matter how cruel someone's treatment is, it will not stop being a human being and still have these rights (Asplund, 2009).

Several principles have imbued international human rights, among others; The principle of equality (equality) is an idea that puts everyone born free and has equality in human rights, where in the same situation it must be treated the same and in different situations treated differently (Indah, 2015). Everyone is equal as a human being. Specifically, Article 1 of the UDHR states that: "Every human being is born free and equal in dignity and dignity". In other words, if we acknowledge that it hurts to humankind and we live together, we should take care of those equality values.

Furthermore, the prohibition of discrimination (nondiscrimination). If everyone is considered to be equal, then there should be no discriminatory treatment as well as affirmative action in order to achieve equality. Basically, discrimination is a difference in behavior from treatment that should be equal or equal (Indah, 2015; Utami, 2019). Non-discrimination is integrated in equality. This principle ensures that no one can exclude other people because of external factors, such as harmony, color, color, sex, language, religion, politics or other views, nationality, ownership of birth status or other (Utami, 2019; Widodo, 2011).

Historical learning is important as a determinant of the success of the process of transferring human rights values contained in historical events to students, students, and society in general. For example, for example the Semanggi tragedy in 1998, the 1998 Student demonstration, the handling of the conflict in West Papua in 2019, and the student demonstration in 2019 if studied in a human rights review, in an effort to respond to these events the government should take a diplomatic approach, dialogue with the parties. -related parties have been carried out, do not take shortcuts with dehumanizing actions that violate human rights.

Referring to this, a lecturer can convey to students about the human rights values that exist in every historical event. So it is important to pay attention to reviews through historical methods and models as an effort to support the success of a transfer of human rights values contained in every historical learning.

\section{Reflecting the Values of Human Rights Awareness in Everyday Life}

In addition to looking for information about the application of human rights values in historical learning, researchers also examined the actualization of human rights values, such as equality and prohibition of discrimination that occurs both within and outside the class. Then the researchers also looked for whether the historical learning process carried out was reflected in students in everyday life. This means that the researcher tries to determine the extent to which the implementation of the values of human rights awareness in historical learning is reflected in the daily lives of students and lecturers.

The values of human rights awareness for lecturers and students are important to be grown, to achieve the educational functions themselves, especially in history learning. As (Mr. AB, 2020) states that it is very important at times because it is not only the existence as stated above, but also how to establish the relationship between students and their lecturers. For example, students value lecturers, so also lecturers appreciate students in their position as human beings whose existence is recognized, and cannot be revoked by anyone. Sometimes the vegetables are like that. There are only students or lecturers who are in the same appreciation for the same, so that there are remarks or actions that should not be done by an educated person. Things like this often appear to be mostly emotional. That is why in Islam it is reminded that emotional times are fast and do wudhu. Because if there is no fate that is what will enter and cause humans to act out of the ordinary. Then (Mr. YB, 2020) argued that: the values of human rights awareness are important for students and lecturers, so that all people (students and lecturers) have awareness of Rights and Obligations." From the two forms of lecturers generally stated that the values of human rights awareness for students and students are grown. 
Then to confirm this matter, the researchers tried to find information through interviews with all ten informants (eleven students at campus A and nine students for campus B) regarding the values of olive human rights awareness regarding equality and the prohibition of discrimination. From campus $\mathrm{A}$ itself, the students' lecturers stated that non-equality practices and discriminatory behavior against students were carried out by lecturers. Like (AF, 2020) argues, there is one lecturer who views student / student physics as a basis for giving grades related to GPA. Subsequently This means that the number is low, the practice is happening in campus $A$.

However, the majority of students (AA, 2020; AB, 2020; AC, 2020; AD, 2020; AH, 2020; AI, 2020; AJ, 2020; and AK, 2020) state that the specific practices of equality and prohibition of discrimination are sufficiently well implemented in the learning process in campus A. For example (AA, 2020) argued "So far none, all are treated the same." Then (AC, 2020) argued nothing. Even when studying muslimbon the history of Islamic thought, my sins are still objective and never discredit anyone. Of the seven other students, it is also true that there is no practice to differentiate between the treatment of teachers towards students as well as the treatment of discrimination in the process of teaching and learning.

Whereas at campus B, of the nine students interviewed, two (BE, 2020; and BH, 2020) students stated that there was a process of discriminating treatment (not equality) and the practice of discrimination. As stated by (BE, 2020) that: There are, sometimes always elevating students who have good grades, and dropping low scores. In other words, even though the calculation is small, according to the admission of the students it turns out that in the historical education program, campus $\mathrm{B}$, there is still the treatment in question. Meanwhile, the other seven students (BA, 2020; BB, 2020; BC, 2020; BD, 2020; $\mathrm{BF}, 2020$; and $\mathrm{BG}, 2020$ ) stated that there were no differences in the practice of treatment or discrimination. For example, the statement (BB, 2020) argues that: when studying in class, the lecturer is objective, all students are treated equally by the lecturer, but when outside the class, some students who have a tendency or are more familiar with these concentrations, according to the facts, are still limited to fairness, because sometimes there are some students who tend to recognize the content. Then (BI, 2020) argues as long as we do not get discriminatory behaviors that have historically been carried out in or outside the classroom. Historical dosage is very humble to the students, I behave positively because it affects the closeness between students and lecturers. This very positive closeness is done to increase awareness not only in the classroom, but also outside the class, I can also be accepted if I want to do a learning discussion outside the class. "

Likewise, with five other students who stated that the practices of difference in treatment (equality) and discrimination on campus B, especially in historical education programs, did not exist. Then the researchers also tried to explore, the impact of the values of human rights awareness on students after learning the history that is reflected in everyday life both inside and outside the class. Such as (Mr. AB, 2020 ) implicitly stated that the practice might be implicit, Not all understanding of that understanding. It may be that there is no understanding of human rights or in the material presented it does not identify as a human rights issue. Because the material discussed is usually not explicitly conveyed that the material is about human rights. Meanwhile (Mr. YB, 2020) argued that: There are several students. But there are also some students who have not changed.

From these two forms, it is sufficient to emphasize that the intended reflection has been practiced at least, although there are also some students who do not know about it. Meanwhile, according to the ten students admitting, there were sixteen who stated that the reflection of human rights awareness has been practiced. For example (AA, 2020) argues that: there is, it can be seen from how many students and students appreciate their opinion even though they are opposed to our opinion. Then (AC, 2020) said there is, we value and respect the existing differences. Then $(B C, 2020)$ argued that according to my opinion, even though the characteristics of each student are different, some apply it immediately and some apply it later on. Only the two students (BA, 2020 and BH, 2020) who stated not yet, as well as the other students (AE, 2020 and AG, 2020) who admitted they did not know and had not paid attention.

It appears that the values of human rights awareness such as equality and the prohibition of discrimination generally occur in campuses A and B, which in practice are in accordance with what the students feel. However, if speaking in general conclusions, the majority stated that the practices in question did not occur, as conveyed by most of the informants who were also students at campuses A and B. Meanwhile, the behavior that reflected human rights awareness was quite visible, it was evident from the twenty students that water can be seen as both students at campuses A and B.

\section{Conclusion}

In general, it can be concluded that historical learning with the values of Human Rights is very close. In even more specific educational objectives, namely the aims of historical learning alone have the 
values of Human Rights. Such values of sympathy and empathy are then reflected in the values of equality and prohibition of discrimination. Its means that optimization of history learning in classroom spaces is very important, so that a primary objective of historical education and learning can be achieved. Then historical learning in which there can be life lessons (lessons) so that the human rights values contained in every historical event can be achieved.

\section{References}

Asplund, K. (2009). Resistance to human rights in Indonesia: Asian values and beyond. Asia-Pacific Journal on Human Rights and the Law, 10(1), 27-47. https://doi.org/10.1163/138819009X12589762582538

Bajaj, M. (2012). From "time pass" to transformative force: School-based human rights education in Tamil Nadu, India. International Journal of Educational Development, 32(1), 72-80. https://doi.org/10.1016/j.ijedudev.2010.10.001

Bedau, H. A. (2016). Universal Human Rights in Theory and Practice by Jack Donnelly. Human Rights Quarterly, 14(1), 142-145. http://www.jstor.org/stable/762557.

Castro-Peraza, M. E., García-Acosta, J. M., Delgado, N., Perdomo-Hernández, A. M., Sosa-Alvarez, M. I., Llabrés-Solé, R., \& Lorenzo-Rocha, N. D. (2019). Gender identity: The human right of depathologization. International Journal of Environmental Research and Public Health, 16(6), 1-10. https://doi.org/10.3390/ijerph16060978

Emmert, S., \& Eur, L. L. M. (2011). Education in terms of human rights. Procedia - Social and Behavioral Sciences, 12, 346-361. https://doi.org/10.1016/j.sbspro.2011.02.044

Horohiung, V. (2017). Pengaruh Strategi Pembelajaran dan Kemampuan Berpikir Kritis Terhadap Hasil Belajar Sejarah Siswa SMA Negeri 72 Jakarta. Jurnal Pendidikan Sejarah, 6(1), 1-10. https://doi.org/10.21009/JPS.061.01

Indah, A. V. (2015). Jatidiri Manusia Berdasarkan Filsafat Tindakan Hannah Arendt Perspektif Filsafat Manusia: Relevansi Dengan Pelanggaran HAM Tahun 1965-1966 Di Indonesia. Jurnal Filsafat, 25(2), 277-315. https://doi.org/10.22146/Jf.12686

Isenström, L., \& Quennerstedt, A. (2020). Governing rationalities in children's human rights education. International Journal of Educational Research, 100(October 2019), 101546. https://doi.org/10.1016/j.ijer.2020.101546

Jumardi, J. (2017). Peranan Pelajaran Sejarah Dalam Pengembangan Karakter Siswa melalui Pembelajaran Berbasis Nilai Sejarah Lokal di SMA Negeri 65 Jakarta Barat. Jurnal Pendidikan Sejarah, 6(2), 7080. https://doi.org/10.21009/JPS.062.08

Kim, G. (2019). "Why is studying hard a violation of human rights?": Tensions and contradictions in Korean students' reasoning about human rights. Journal of Social Studies Research, 43(3), 255267. https://doi.org/10.1016/j.jssr.2018.06.001

Košir, S., \& Lakshminarayanan, R. (2020). Inclusion of 'generations of human rights' in social science textbooks. International Journal of Educational Development, 80(November 2020). https://doi.org/10.1016/j.ijedudev.2020.102295

Manuchehr, T. N. (2010). UNO and the human rights education. Procedia - Social and Behavioral Sciences, 2(2), 1249-1252. https://doi.org/10.1016/j.sbspro.2010.03.182

McLeod, J. (2014). A Peaceful Pedagogy: Teaching Human Rights Across the Curriculum. Procedia - Social and Behavioral Sciences, 152, 1225-1232. https://doi.org/10.1016/j.sbspro.2014.09.303

Permatasari, E. A. (2014). Implementasi pendekatan saintifik dalam kurikulum 2013 pada pembelajaran sejarah. Indonesian Journal of History Education, 3(1). https://journal.unnes.ac.id/sju/index.php/ijhe/article/view/3884

Rodrigues, R. (2020). Legal and human rights issues of AI: gaps, challenges and vulnerabilities. Journal of Responsible Technology, 100005. https://doi.org/10.1016/j.jrt.2020.100005

Ruslan, A., \& Syukur, A. (2020). HOTS (High Order Thinking Skills) Dan Kaitannya Dengan Nilai-Nilai Hak Asasi Manusia Dalam Pembelajaran Sejarah. Prosiding Seminar Nasional Pascasarjana, 1(1), 43- 
52. http://journal.unj.ac.id/unj/index.php/semnas-ps/article/view/16851

Shekarey, A., Zare-ee, A., Haji Rashidi, H., \& Sedaghat Rostami, M. (2010). Human rights education in Iranian secondary education: Gaps in the curriculum. Procedia - Social and Behavioral Sciences, 5, 2103-2107. https://doi.org/10.1016/j.sbspro.2010.07.421

Soraya, D., Jampel, I. N., \& Diputra, K. S. (2018). Pengaruh Model Pembelajaran Problem Based Learning (PBL) Berbasis Kearifan Lokal Terhadap Sikap Sosial dan Berpikir Kritis Pada Mata Pelajaran Matematika. Thinking Skills and Creativity Journa;, 1(2), 76-85. https://doi.org/10.23887/tscj.v1i2.20409

Sugiyono. (2012). Metode Penelitian Pendidikan (Pendekatan Kuantitatif, Kualitatif dan R\&D. Alfabeta.

Suhadi, S. (2007). Azazi Manusia dan Aktualisasinya di Indonesia. Universitas Gajah Mada.

Triputra, Y. A. (2017). Implementasi Nilai-Nilai HAM Global Ke dalam Sistem Hukum Indonesia yang Berlandaskan Pancasila. Jurnal Hukum Ius Quia Iustum, 24(2), 279-300. https://doi.org/10.20885/iustum.vol24.iss2.art6

Utami, I. W. P. (2019). Teaching Historical Empathy Trough Reflective Learning. Paramita: Historical Studies Journal, 21(1), 1-9. https://doi.org/10.15294/paramita.v29i1.11479

Widodo, T. (2011). Memahami Makna Praksis Pelaksanaan Pembelajaran Sejarah Kontroversial. Paramita: Historical Studies Journal, 21(2). https://doi.org/10.15294/paramita.v21i2.1043

Wong, M. Y. H., Kwong, Y. ho, \& Chau, V. Y. W. (2020). Democracy, constitutional framework, and human rights: A comparison of Monaco, Tonga, Hong Kong, and Singapore. International Journal of Law, Crime and Justice, 64(September 2020), 100438. https://doi.org/10.1016/j.ijlcj.2020.100438 